\title{
Implikasies van die prosesse van transformasie vir die universiteitswese in Suid-Afrika
}

\author{
Willie Esterhuyse \\ Departement Filosofie \\ Universiteit van Stellenbosch \\ STELLENBOSCH
}

\begin{abstract}
This article addresses a contentious political and policy issue: the implications which the process of change currently taking place in South Africa hold for traditional 'white' universities. It is argued that this issue should be addressed, on the one hand, from the perspective of sociopolitical transformation and, on the other hand, from the perspective of modernizing development. These two major transformational processes determine the context in which universities need to restructure and position themselves. The implications of these processes for traditional 'white' universities in general and Afrikaans universities in particular are analysed in terms of three distinctive categories or levels of issues:

- The nature, function and mission of the university as an academic institution.

- $\quad$ The organizational structure of the university.

- The organizational culture, social structure and value system of the university as a community of people.

It is concluded that the desegregation of traditional 'white' universities has been but the first step in the complicated process of transforming South African universities.
\end{abstract}

\section{Inleiding}

Dwarsoor die wêreld, in ontwikkelde én ontwikkelende lande, staan die universiteitswese tans onder die vergrootglas. In die groeiende literatuur hieroor word daar alreeds soveel uiteenlopende standpunte, menings en nuwe visies verdedig dat dit 'n groot versoeking word om maar te volstaan met die opmerking van Russell Berman (1989:116) in sy artikel met die titel "Perestroika for the University" dat "Yankee ingenuity" en "self-interested practice" ongeveer die volgende soort 'tydsgees' geskep het: 
Implikasies van die prosesse van transformasie vir die universiteitswese in Suid-Afrika

Making a buck is better than thinking a thought (Marx); knowledge is power and might makes right (Foucault); truth is falsehood (Derrida); the university is, for the student, a career-facilitating office, and for the faculty a shared zerox machine cum mailing privileges. For the government, it is just another client.

Sedert sy ontstaan was die universiteit natuurlik dikwels in die gedrang. Vanweë sy eiesoortige aard en funksie, maar veral ook vanweë die wyse waarop die universiteit enersyds deur ander instellings (soos kerk en staat) en andersyds deur sy eie personeel beskou is, was dit eintlik noodwendig dat daar voortdurend 'n herwaardering plaasgevind het van die plek van die universiteit in 'n veranderende samelewing.

In hierdie opsig is die soort vrae wat tans in Suid-Afrika oor die universiteit in die algemeen en Afrikaanstalige universiteite in die besonder gevra word, nie vreemd of uit pas met die geskiedenis van die universiteit nie. Dit is, om dit so te stel, deel van die intellektuele geskiedenis van die universiteit dat 'n permanente vraagteken oor sy aard, rol en missie hang. Dat dit die geval is, blyk byvoorbeeld uit artikels met opskrifte soos "Universities in Transition" (Rothman, 1992) en "The Spiritual Impoverishment of the German University" (Heinrich, 1989), asook boeke soos The Closing of the American Mind: How Higher Education has Failed Democracy and Impoverished the Souls of Today's Students (Bloom, 1987) en The Future of Intellectuals and the Rise of the New Class (Gouldner, 1979).

Vanuit 'n historiese perspektief gesien, is die vraag na 'n grondige herwaardering van 'n universiteit se rol in die lig van nuwe omstandighede dus geen nuwe vraagstuk nie. Nuwe vraagstukke duik reëlmatig gedurende tye van ingrypende veranderings op, dit wil sê veranderings wat nie bloot aanpassings van of verstellings aan ' $n$ bepaalde sisteem of stelsel is nie, maar wat van ' $n$ strukturele of transformatiewe aard is. En omdat die verandering struktureel en transformatief is - of radikaal en epogaal-revolusionêr (oftewel 'n revolusie oor tyd heen) - woel dit ook die etos en waardestelsel van die veranderde samelewing om. Dit is die rede waarom byvoorbeeld die debat oor waardes juis gedurende transformasieprosesse bo aan die agenda beland, ' $n$ feit wat tans baie goed geillustreer word deur die gesprek oor waardes wat daar tydens die strategiese beplanningsessies van groot Suid-Afrikaanse ondernemings plaasvind

Ten einde veralgemenende uitsprake te vermy, sal daar in hierdie artikel eers aandag gegee word aan wat die proses van sosio-politieke transformasie genoem word. Die aard van hierdie proses asook die vernaamste tendense wat dit ontsluit, sal kortliks ontleed word. Die transformasieproses vorm immers 'n belangrike konteks waarbinne oor die toekoms van Afrikaanstalige universiteite gepraat moet word. Die implikasies van die sosio-politieke transformasieproses is na alle 
waarskynlikheid die mees belangrike - en dramatiese - vir universiteite oor die korter tot mediumtermyn.

Suid-Afrika is natuurlik nie net in 'n proses van sosio-politieke oorgang of transformasie nie. Die land is bowendien ook in die posisie dat dit, meer as talle ander lande op ons kontinent, die proses van moderniserende ontwikkeling ervaar het en nog steeds ervaar. Trouens, as die eerste proses slaag, sal hierdie onderliggende proses myns insiens verdere momentum ontvang.

Dit is daarom wenslik dat ook stilgestaan sal word by die aard van hierdie proses en die soort tendense wat daarmee saamhang. Saam met die proses van sosiopolitieke transformasie, bepaal die proses van moderniserende ontwikkeling op 'n wesenlike wyse die konteks waarin nagedink moet word oor hoe ons die universiteit sien, wat ons dink sy missie is, hoe ons dink leerplanne ingerig moet word, wat ons as navorsingsprioriteite beskou, en wie ons dink die primêre fokus van ons opleidings-, opvoedings- en diensleweringsrol moet wees.

In die volgende betoog sal eers aandag gegee word aan die proses van sosiopolitieke transformasie. Daarna sal stilgestaan word by die proses van moderniserende ontwikkeling. Wat dit alles vir die universiteit inhou, sal uiteindelik die hoofkomponent van die betoog uitmaak.

\section{Sosio-politieke transformasieprosesse}

Dit word algemeen aanvaar dat die RSA in 'n oorgangsproses (transition) is. Hierdie tipe veranderingsprosesse is nie alleen baie fundamenteel en ingrypend nie, maar kan selfs ' $n$ dekade of langer duur. Kenmerkend van hierdie prosesse is dat die toekoms 'n 'bewegende teiken' (Pierre Wack) word, dit wil sê dit is nie stabiel nie en geen 'korrekte' projeksie na die toekoms kan in terme van die gedrag van die verlede en hede gemaak word nie.

Die proses wat hier ter sprake is, kan soos volg gedefinieer word:

Oorgange is strukturele transformasies op alle gebiede of vlakke van 'n samelewing, soos byvoorbeeld die politieke, ekonomiese, sosiale en opvoedkundige gebicde, met as gevolg 'n drastiese wysiging van die mags- en gesagsverhoudinge wat in daardie samelewing geheers het

O'Domnell en Sclumitter, in hulle uitstekende studie, Transitions from Authoritarian Rule (1986), wys daarop dat hierdie soort prosesse, wanneer die doelwit 'n demokrasie is, drie onderskeibare fasette vertoon wat met mekaar kan oorvleuel, naamlik: liberalisering, demokratisering en sosialisering. Vir die doeleindes van die onderwerp is dit nodig om baie kortliks by hierdie fasette stil te staan. 


\section{* Liberalisering}

Liberalisering behels enersyds die 'oop' maak van die samelewing en andersyds die verlening van regte aan diegene wat voorheen daarvan uitgesluit was. Liberalisering skep beweeg- en aksieruimte vir diegene teen wie gediskrimineer is en lei noodwendig tot druk vir regstellende aksies en die uitskakeling van ongelykhede. Gewoonlik lei liberalisering ook tot reekse onbedoelde en onbeplande gevolge - veral wat waardestelsels betref. Die maghebbende elite en sy ondersteuningsgroep verloor immers algaande hulle voorskriftelike posisie ten opsigte van wat as normgewend sal geld. Daar is, om dit so te stel, nie meer 'n politieke veiligheidsnet vir daardie instellings en groepe individue wat voordeel uit die ou bedeling getrek het nie. Liberalisering lei nie noodwendig tot demokratisering nie; dit gaan ongelukkig ook gewoonlik gepaard met onnus, magstryde en geweld.

\section{* Demokratisering}

Demokratisering, soos Huntington (1991), Dahl (1971) en Rustow (1970) aantoon, is die proses waardeur die reëls, regte en prosedures vir burgerskap, politieke deelname en aanspreeklikheid toegepas word ten opsigte van politieke instellings, groepe wat voorheen polities en andersins onderdruk is en sake ten opsigte waarvan die burgery geen toegang tot deelname, byvoorbeeld in die vorm van 'n kritiese debat, gehad het nie.

Dit moet in dié verband beklemtoon word dat demokratisering noodwendig deelname beteken asook groter aanspreeklikheid van gesagsinstansies aan diegene vir wie hulle as verteenwoordigers en trustees optree. Omdat dit die geval is, is die bou van ' $n$ dinamiese demokratiese kultuur gedurende die proses van demokratisering - en natuurlik die onderhouding en uitbouing van daardie kultuur ná die vestiging van ' $n$ demokrasie - een van die talle voorwaardes vir sukses. Dit is een van die belangrike redes waarom die proses van demokratisering direkte betrekking op ' $n$ universiteit het - enersyds, wat sy rol betref, in die bou en onderhou van 'n demokratiese kultuur en andersyds ten opsigte van sy eie aard en funksionering - iets waarop later terug gekom sal word.

\section{* Sosialisering}

Die proses van sosialisering behels die konsolidasie van die gedemokratiseerde samelewing op die vlakke van waardes, belange en instellings asook politieke, sosiale, ekonomiese en ander aktiwiteite. Die kwessie van sosialisering, en die sukses daarvan, hou direk verband met die vraag of daar in Suid-Afrika - ten spyte van verskeidenheid - ' $n$ konsensus oor fundamentele waardes, norme en beginsels sal ontwikkel en of daar eenheidstigtende simbole, rites en 'verhale' na die oppervlakte sal kom. Dit gebeur natuurlik nie vanself of outomaties nie, maar hang onder andere af van opvoedings- en interaksieprosesse. 
Die prosesse van liberalisering, demokratisering en sosialisering is uiters kompleks, ontwikkel oor tyd heen en vind nooit sonder terugslae plaas nie. Hoe meer belangegroepe die proses verstaan en daaraan deelneem, hoe beter.

Soos reeds aangedui is, is die proses van sosio-politieke transformasie nie die enigste strukturele veranderingsproses wat Suid-Afrika ervaar nie. Die ander strukturele veranderingsproses is dié van moderniserende ontwikkeling.

\section{Moderniserende ontwikkelingsprosesse}

Hierdie proses hou verband met die opgang en die invloed van die wetenskap en die tegniek, die rol wat dit in die hedendaagse wêreld speel en die feit dat dit 'n sentrale aandrywer van ontwikkeling geword het, iets wat die onderwerp van talle insiggewende studies geword het soos onder andere John Ziman se boek met die betekenisvolle titel The Force of Knowledge (1977) of Langdon Winner se artikel "Citizen Virtues in a Technological Order" (1992). Indien die sosio-politieke oorgangsproses in Suid-Afrika suksesvol verloop, kan aanvaar word dat die proses van moderniserende ontwikkeling momentum sal kry. Suid-Afrika se blootstelling aan internasionale prosesse en tendense sal daarmee ook groter word. Adapting Universities to a Technological Society, om die titel van 'n boek van Eric Ashby (1974) te gebruik, is 'n uitdaging waarvoor ook Suid-Afrikaanse universiteite in al groter wordende mate te staan sal kom.

Moderniserende ontwikkeling is nie bloot 'materieel' van aard nie. Die inhoud en omvang daarvan gaan nie volledig op in aanwysbare sake soos rekenaars, woordverwerkers, outomatiese telefoonsentrales, televisiestelle, vliegtuie of 'slim' projektiele nie. Moderniserende ontwikkeling sluit ook ander, meer verfynde en nuwe bestuursprosesse, manipulasietegnieke en beheersisteme in. Daarbenewens gaan dit ook gepaard met meer pragmatiese waardestelsels en die beklemtoning van kwessies soos doeltreffendheid, kwaliteitsbeheer en produktiewe tydsbesteding. Anders gestel, moderniserende ontwikkeling is ' $n$ vorm van ontwikkeling wat sonder die wetenskap en die tegniek ondenkbaar sou gewees het, wat die materiële én intellektuele omstandighede van die mens drasties gewysig het en wat tot nuwe waardestelsels aanleiding gegee het. Die neerslag daarvan is duidelik sigbaar in die sogenaamde ontwikkelde lande.

'n Kanttekening is hierby nodig. Die aksent op moderniserende ontwikkeling, met as implikasie dat Suid-Afrika op hierdie stadium 'n ontwikkelende land is, mag die indruk van Eurosentrisme wek en die mening vestig dat die sogenaamde Eerste of ontwikkelde wêreld die RSA se enigste sfeer van interaksie behoort te wees. Dit sal ' $n$ verkeerde indruk en mening wees. 
Wat met die aksent op moderniserende ontwikkeling gesê word, is dat SuidAfrika - met sy reeds inherente strukturele spanning tussen industriële kultuur en agrariese kultuur - hierdie spanning in verskerpte mate sal ervaar namate die land demokratiseer én moderniseer. Dit mag selfs na 'n vorm van Hegeliaanse vooruitgangsoptimisme klink, maar dit kan ook aanvaar word dat die proses van moderniserende ontwikkeling - met sy gepaardgaande industrialisering en verstedeliking - oor die volgende 30-50 jaar in versnelde tempo sal toeneem.

Voordat iets oor die proses van modemiserende ontwikkeling gesê word, is die volgende opmerking gepas:

Kenmerkend van die hedendaagse sogenaamde ontwikkelde en gemodemiseerde samelewing is dat daar nie skerp afgebakende en veral gestabiliseerde patrone van prosesse en tendense is soos in 'n agrariese kultuur met sy meer stabiele ordeninge nie. Verandering, dinamiek en steeds opduikende nuwe moontlikhede en posisies is eerder tipies van die ontwikkelde en gemoderniseerde kultuur: dis immers 'n kultuur wat staan in die teken van die wentelende roltrap, die snelweg, die faksmasjien en die persoonlike rekenaar. Van hierdie kultuur en tydsgees kan daar, soos Willie van der Merwe (1989:345) dit in sy artikel oor "Die hedendaagse Westerse kultuur" stel, nie op 'n ander wyse gedink en gepraat word as "deur teenstellings en weersprekings" heen nie.

Met hierdie belangrike punt wel in gedagte - dit sal ons van apodiktiese uitsprake bewaar - sal daar tog met behulp van 'n aantal sleutelbegrippe enkele tendense binne die proses van moderniserende ontwikkeling geïdentifiseer word

\section{* Demokratisering}

Die eerste een is die tendens tot demokratisering, 'n tendens waarna reeds verwys is. Hieroor bestaan daar reeds ' $n$ indrukwekkende korpus literatuur én 'n ewe indrukwekkende debat oor hoe die invloed van die wetenskap en tegniek op die demokrasie self geïnterpreteer moet word - soos onder andere vertolk deur Yaron Ezrahi in sy boek: The Descent of Icarus. Science and the Transformation of Contemporary Democracy (1990). Daar kan nie op hierdie debat ingegaan word nie. Wat wel duidelik behoort te wees, is dat demokratisering, binne die verband van moderniserende ontwikkeling, 'n horisontalisering van gesagsverhoudinge beteken, ' $n$ beklemtoning van deelname en 'n ondermyning van hiërargiese patrone. Heteronome waardestelsels swig ook binne die proses van moderniserende ontwikkeling voor die druk van selfbepaling en vryheid van keuse. In 'n gemoderniseerde en gedemokratiseerde samelewing kan daar nie meer eensydig aan mense voorgeskryf word wat hulle moet dink en doen nie. 


\section{* Desentralisering en differensiëring}

'n Tweede tendens, wat baie nou met die vorige saamhang, is die tweelingtendens van desentralisering en differensiëring. Nie-hiërargiese strukture ontstaan. Keusemoontlikhede word uitgebrei. So ook assosiasiepatrone en waardestelsels, 'n tendens wat terloops gewoonlik gevoed word deur liberaliseringsprosesse en die uitbreiding van regte. Dit alles lei uiteindelik tot 'n pluralistiese samelewingsvorm asook 'n gepaardgaande pluralistiese 'mentaliteit' waarin weggebreek is van outoritêre denkstyle en totalitêre lewensbeskouinge. 'Klein', in plaas van 'groot', word belangrik. Die 'dele' - en nie die 'geheel' nie - word as deurslaggewend beskou, 'n gegewe wat deurspeel in die wydgelese boek van Tom Peters: Liberation Management (1992)

\section{* Sekularisering}

'n Derde tendens, genaelstring aan die voorafgaande, is die tendens tot sckularisering - oftewel die 'ontgoddeliking' van die wêreld en die proklamering van eie selfstandigheid en outonomie, 'n uitdagende tema wat die onderliggende onderwerp van die nog steeds tersaaklike studie van Hans-Rudolf MüllerSchwefe oor Technik und Glauhe (1971) is. 'n Mens sou dit ook anders kon stel: moderniserende ontwikkeling laat die mens homself ontdek as outeur van die geskiedenis, vrygemaak van magte en kragte waaroor hy voorheen geen beheer gehad het nie. Die woord God verloor sy tradisionele en geykte grondslaggewende funksie en die dogmatiek sy rigtinggewende betekenis. Die etiek kom op die agenda. God self word, positief gesien, vrygemaak van begripmatig geformuleerde skemas, beelde en stigtende konstruksies.

\section{* Operasionalisering}

Hierdie tendens word versterk deur 'n vierde tendens, naamlik die tendens tot operasionalisering, oftewel die bruikbaarmaking van kennis en insigte, gepaardgaande met die oortuiging dat die waarde van iets lê in die gebruik wat daarvan gemaak kan word. Trouens, hierdie utilitaristiese lewenshouding is na alle waarskynlikheid die mees tipiese aspek van die 'gees' van ons tyd. Daarin word die kern van moderniserende ontwikkeling vertolk, naamlik die feit dat die praktiese toepassing van wetenskaplike insigte en tegniese kundighede die spil is waaromheen die ontwikkelde wêreld wentel. Dit is ook in die operasionaliseringstendens dat die hedendaagse mens sy triomf oor die agrariese kultuur kan vier en kan oordeel dat dit wat nie op handeling afgestem is nie of nie omgeskakel kan word in praktiese toepassingsvorme nie - of dit nou politieke ideologieë, godsdienstige oortuigings of geykte waardestelsels is - nie die moeite werd is om ernstig op te neem nie 


\section{* Relativering}

Al hierdie tendense bevorder 'n laaste tendens wat genoem moet word, naamlik dié van relatıvering en die gepaardgaande paradigmatiese verskuiwing tell aansien van opvattings oor waarheid en 'ewige' grondslae. Daar is nie meer, om dit so te stel, een waarheid wat vry maak nie. Uitwaaierende en selfs kontrasterende moontlikhede is eerder die geval. Postmodernisties uitgedruk - die wêreld en die mens is sonder ewigdurende vaste grond

Die belangrike vraag is nou wat die implikasies van die prosesse van sosiopolitieke oorgang en modemiserende ontwikkeling vir veral die tradisionele Afrikaanstalige universiteite is. Is dit enigsins prosesse en tendense wat vir hulle ter sake is? Kan ons nie aanvaar dat alle universiteite die storms en veranderinge van die tye sal oorleef en hul 'identiteit' sal behou nie?

\section{Implikasies}

In alle ontwikkelde lande word aanvaar dat 'n tyd van snelle en ingrypende verandering voor hande is vir onderwys- en opleidingsinrigtings wat die eise, verwagtings en uitdagings van die $21 \mathrm{e}$ eeu wil ontmoet. "Education and Learning in the 21st Century" (Marien, 1992) staan reeds as sentrale tema op die agenda. So ook die vraag na A University of the Finture (Berstecher et al., 1974). Rossouw (1989) praat selfs van "die universiteit by die kruispad".

Wat Suid-Afrika self betref, is die implikasies van die twee prosesse waarna hierbo verwys is na alle waarskynlikheid legio. Talle daarvan sal ook eers oor tyd heen na die oppervlakte kom. Wat ons reeds weet, is dat die tradisionele wit Afrikaanstalige universiteite se formele én veral informele politieke veiligheidsnet (informeel: persoonlike kontakte, ens.) binne afsienbare tyd ten dele of moontlik selfs heeltemal sal verdwyn - iets wat ons hopelik beter sal laat verstaan wat universitêre outonomie en akademiese vryheid beteken.

Daar is egter veral drie kwessies ten opsigte waarvan die oorgangsproses in die RSA redelik drastiese gevolge vir ons universiteite sal hê. Daaraan sal in die volgende aantal paragrawe aandag gegee word.

\subsection{Die aard, funksie en missie van die universiteit}

Die eerste kwessie het betrekking op die aard, funksie en missie van die universiteit as 'n akademiese instelling. Dié debat wat reeds besig is om meer openbaar te word, wentel veral rondom die volgende twee 'spanningspole':

* Die 'identiteit' van die universiteit as 'n akademiese instelling en sy 'legitimiteit' as 'n sosiale en diensinstituut (of samelewingstruktuur). 
* Die kwessie van 'uitmuntendheid' (excellence) wat, soos 'n ANC-er dit stel, nou skielik in die oorgangsproses tot alleensaligmakende waarde verhef word, en 'relevansie' (relevance) binne 'n bepaalde sosio-ekonomiese en politieke konteks.

Liberaliserings- en demokratiseringsprosesse het direk betrekking op die aard, funksie en missie van die universiteit as 'n akademiese instelling asook op die 'spanningspole' waarna hierbo verwys is. Die kern van die betrekking word tans versimboliseer in die begrip regstellende aksie - 'n term wat reeds vir ons sê dat die legitimiteit of morele aanneemlikheid van tradisionele wit universiteite nie net bepaal gaan word deur die gehalte van hulle navorsing of doseerwerk nie, maar ook - miskien veral - deur die beleid wat hulle volg ten opsigte van die volgende:

* Die toeganklikheid van die universiteit vir sosio-polities benadeelde studente met 'n fokus op:

- toelatingsbeleid,

- finansiële ondersteuning,

- algemene ondersteuning,

- oorbruggingsprogramme,

- akademiese standaarde

* Die 'relevansie' en 'toepaslikheid' van leerplanne, kursusinhoude én navorsingsprioriteite.

* Die sensitiwiteit vir en aanspreeklikheid ten opsigte van die behoeftes van die gemeenskap in die algemeen en sosio-polities benadeelde groepe in die besonder. Die standpunt word reeds verdedig dat diegene wat oor tyd heen bevoordeel is, kollektief en institusioneel aanspreeklik is vir ongelykhede vanweë diskriminerende praktyke en onderdrukkende beleide.

* Die 'toerusting' van doserende personeel om dit alles te kan hanteer, veral personeel wat van multikulturele en meerrassige situasies geïsoleer was.

Hierdie sake kom noodwendig op die agenda in multikulturele en meerrassige samelewings wat veranderings in die heersende mags- en gesagsverhoudinge ervaar. Wat in die VSA gedurende die sestigerjare gebeur het, is hiervan 'n baie goeie illustrasie. En dit kom veral vir daardie universiteite op die agenda wat simbolies van wit bevoorregting en wit dominansie is. Daarom word die debat oor hierdie sake nóóit bloot in ' $n$ akademiese en rasionele konteks gevoer nie. Dit word polities 'gekleur' - juis ook omdat die probleem waaroor dit gaan van 'n sosio-politieke oorsprong is. Anders gestel, die politisering van die universiteit as 'n akademiese instelling binne 'n samelewing wat deur strukturele diskriminasie gekenmerk word, sluit uit dat die gesprek oor die aard, funksie en missie van die 
Implikasies van die prosesse van transformasie vir die universiteitsw'ese in Suid-Afrika

universiteit binne 'n omgewing wat sosio-polities geherstruktureer word, bloot akademies en rasioneel-onbetrokke kan wees.

Dit is teen hierdie agtergrond gesien dat die National Education Coordinating Committee (NECC) se aksent op die 'politieke' vereistes van equality, nonracism, non-sexism, democracy en redress verstaan moet word wanneer daar oor die transformasie van die onderwys in Suid-Afrika gepraat word. Daarom word daar in hierdie geledere, wanneer die universiteit as akademiese instelling ter sprake kom, ook daarvan gewag gemaak dat tradisionele wit universiteite nie bloot 'wit' was omdat hulle meer wit as swart studente - of selfs géén swart studente - gehad het nie, maar omdat hulle in hulle onderrig, opvoeding en navorsingsprioriteite, asook die tipe kursusse wat aangebied is en selfs vakbenaminge, gerig was op die wêreld van wit waardes en belange. In die geval van Afrikaanstalige universiteite is die amptelike ideologie boonop versterk.

Dit is nie moontlik of selfs nodig om in te gaan op die sake wat hierbo as agendapunte onder die rubriek van die aard, funksie en missie van die universiteit as 'n akademiese instelling genoem is nie. 'n Blaadjie uit die boek van die VSA oor tersiêre onderwys en opvoeding sal wel toon dat ons hier voor 'n uiters komplekse probleem staan. Die meeste universiteite in die VSA is deur diegene teen wie op grond van hulle ras en kleur gediskrimineer is, as elitistiese wit instellings beskou wat gerig was op die belange, kultuur en behoeftes van blankes - wat ook al oor die missie en standaarde van die universiteit gesê is. Talle kursusse en vakinhoude is as 'irrelevant' afgemaak vanweë die universiteite se beweerde oriëntasie op die dominante 'wit' kultuur, sy waardes, prestasies, gevestigde belange en magsverhoudinge.

'Relevansie' is op 'n tweeledige wyse geïnterpreteer: enersyds as die prioriteitstelling van die behoeftes en aspirasies van histories benadeelde groepe; andersyds as die transformasie van die universiteit tot 'n agentskap vir verandering en 'n voertuig vir kompensatoriese aksies.

Wat ook al die negatiewe fasette van hierdie benadering was, het dit wel iets op die agenda geplaas wat tans vir die meeste Suid-Afrikaanse universiteite en vir Afrikaanstalige universiteite in die besonder van kardinale belang is, naamlik hulle legitimiteit as akademiese instellings in 'n multikulturele en meerrassige samelewing. Daarom is die krisis waarin tersiêre onderwys tans verkeer ook nie bloot reduseerbaar tot 'n krisis oor finansiering, bestuur, fasiliteite of doeltreffendheid nie. Dis ook 'n legitimiteitskrisis.

\subsection{Die organisasiestruktuur van die universiteit}

Die tweede kwessie wat ter sprake is, hou verband met die organisasiestruktuur van die universiteit en word in fokus gebring deur veral die proses van demo- 
Willie Esterhuyse

kratisering. In die debat wat dit reeds tot gevolg gehad het, moet die volgende punte benadruk word:

* Die herstrukturering van besluitnemingsprosedures met 'n aksent op nieoutoritêre, nie-paternalistiese deelnemende bestuurstyle asook groter aanspreeklikheid (accountability).

* Die samestelling van besluitnemingsliggame (byvoorbeeld die Raad en Senaat van die universiteit).

* Die aanstellingsbeleid ('nie-seksisties'; 'nie-rassig'; 'nie-godsdienstig').

* Die konsultasie- en inspraakstrukture tussen die universiteit en die samelewing asook ander belangegroepe.

Daar is natuurlik verskillende en selfs uiteenlopende redes waarom die organisasiestruktuur van die universiteit op die agenda staan - nie net hier te lande nie, maar ook wêreldwyd. Doeltreffendheidsoorwegings, die noodsaaklikheid van finansiële dissipline en algemene bestuursoorwegings is onder andere van hierdie redes. Wat Suid-Afrika betref, is hierdie redes natuurlik ook ter sake, veral ook vanweë die feit dat Suid-Afrikaanse universiteite hoofsaaklik met die publiek en belastingbetalers se geld aan die gang gehou word. Daarom geld aanspreeklikheid, doeltreffende bestuur en dissipline veral vir die universiteit.

Binne die Suid-Afrikaanse konteks is daar egter ook ander redes - selfs belangriker redes - vir institusionele vernuwing. Dit is immers so dat instellings wat oorgangsprosesse wil oorleef, baie gou moet leer om doeltreffendheid met legitimiteit te paar. Doeltreffendheid waarborg nog nie legitimiteit nie - soos wat legitimiteit nie doeltreffendheid waarborg nie. Dié twee kom nie outomaties by mekaar uit nie. Dit vra doelgerigte beplanning en berekende aksie, veral in 'n multikulturele samelewing.

Die belangrike probleem waaroor dit hier gaan, is dié van institusionele verandering. Onderwysinstellings, waaronder veral universiteite, is van daardie instellings wat die moeilikste verander. Hulle is hardnekkig in hulle weerstand teen institusionele vernuwing. Word institusionele vernuwing wel aangepak, is alle probleme nog nie opgelos nie. Daar word byvoorbeeld onmiddellik gestuit op die vrae: Wie moet almal daaraan deelneem? Hoe moet dit gedoen word? In terme waarvan? Watter 'modelle' moet as maatgewend geneem word: familie-modelle, gemeenskapsmodelle, ondernemingsmodelle, burokratiese modelle of tegnokratiese modelle?

In die geval van Suid-Afrika staan die kwessie van die organisasiestruktuur van die universiteit op die agenda vanweë enersyds die proses van politieke demokratisering, met sy gepaardgaande aksent op aanspreeklikheid (accountability) en deursigtigheid (transparency), en andersyds die proses van moderniserende ont- 
wikkeling wat nie alleen hiërargiese gesagspatrone en geykte waardestelsels aantas nie, maar baie hoë eise aan doeltrefffende bestuur stel. Hoe om die nuwe bestuurseise só te hanteer sónder dat die universiteit sy karakter as akademiese instelling verloor en 'n 'onderneming' onder ander ondernemings word, is een van die komplekse vrae wat die sogenaamde tegnokratiese tydsgees aan ons opdwing. Daar heers immers nie net 'bestuursprobleme' aan die universiteit nie. Tegnokrate, of hulle nou konserwatief of links is, wil natuurlik die universiteit - soos die politiek - tot 'n bestuursmatige aangeleentheid reduseer. Hoe hierdie reduksionisme wat met moderniserende ontwikkeling gepaard gaan, teengewerk kan word, is van die soort uitdagings waarvoor ons staan.

Dit alles word meer ingewikkeld gemaak deur beperkings op die finansieringsbronne van Suid-Afrikaanse universiteite. Dit kan aanvaar word dat die 'helpende hand' van die staat aansienlik kleiner gaan.word. Dit is bowendien ook nie uitgesluit nie dat dié hulp toenemend aan prioriteite gekoppel sal wees wat met die land en sy behoeftes in verband staan.

\subsection{Organisasiekultuur, sosiale struktuur en waardestelsel}

Die derde kwessie wat aangeroer moet word, is wat genoem kan word die organisasiekultuur, sosiale struktuur en waardestelsel van die universiteit as gemeenskap van mense. Soos enige ander instelling of onderneming het 'n universiteit ook 'n outentieke organisasiekultuur wat sterk of swak kan wees. Dié kultuur, wat die simbole, waardes, rites, rituele en gedragspatrone van die universiteit omvat, is bepalend vir die legitimiteit sowel as die doeltreffendheid van die universiteit as instelling.

Die soort vrae wat onder andere deur hierdie kwessie opgeroep word, is die volgende:

* Wat is die algemene beeld van die universiteit? Dié van 'n elitistiese wit instelling wat seksionele belange dien? 'n Middel- tot hoër middelklasinstelling wat 'afronding' aan rykes verskaf?

* Hoe sien die doserende, administratiewe en studentesamestelling daar uit veral ten opsigte van geslag, ras en kultuur? Is dit eksklusief in terme van die kriteria van meriete, maar inklusief ten opsigte van geslag, ras en kultuur?

* Hoe verstaan die universiteit sy sosiale verantwoordelikheid en gemeenskapsbetrokkenheid?

* Wat kan as die kernwaardes van die universiteit aangedui word, wie bepaal dit en word dit ook so aanvaar? 
Laasgenoemde vraag is een van die belangrikste vrae wat gedurende oorgangsprosesse gevra kan word. Oorgangsprosesse tas nie alleen gevestigde strukture aan nie. Dit plaas ook druk op geykte waardestelsels, woel hulle meestal om en bring ander, nuwe waardekonsepsies na die oppervlakte. Dit neem ook gewoonlik tyd alvorens ' $n$ meer inklusiewe konsensus oor samelewings- en ander waardes ontwikkel. Wat ons wel kan aanvaar, is dat daar van die eksklusiewe wêreld van 'wit waardes' en gevestigde belange - en veral wit vooroordele wat tot die rang van beginsels verhef is - niks gaan oorbly nie.

In dié verband kan wel 'n optimistiese opmerking gemaak word. Dit is naamlik verstommend watter mate van konsensus daar wel in die land oor fundamentele waardes bestaan; dit moet net ontdek, ontgin en geïnstitusionaliseer word Daarvoor moet natuurlik gesprek gevoer word, ander leiersfigure ontmoet (en erken!) word en aanvaar word dat wit mense gewoon arrogant is as hulle dink dat hulle die alleenbewakers van aanvaarbare waardes, norme en beginsels is.

Wat die kwessie van die organisasiekultuur, sosiale struktuur en waardestelsel van die universiteit self betref, kan ten slotte beklemtoon word dat dit nie genoeg is om bloot te sê - en as beleid te aanvaar - dat die universiteit nie-rassig en nieseksisties is nie. Woorde mag wel wek, maar dit is voorbeelde wat toon dat ' $\mathrm{n}$ aanspraak ook legitiem is. Daarom moet daar met 'n fynkam deur 'n universiteit se kultuur gegaan word op soek na veral daardie konvensies, informele gebruike en gedragspatrone wat met die beleidsaansprake van nie-rassigheid en nieseksisme stry. Dit kan soms ' $n$ pynlike leerproses wees.

Die soort vrae wat gestel moet word oor die universiteit se organisasiekultuur, sosiale struktuur en waardestelsel het veral vir Afrikaanstalige universiteite ' $n$ paar sensitiewe kante

\section{* Mags- en gesagsverhouding}

Die een kwessie hou verband met die mags- en gesagsverhoudinge binne die universiteit as ' $n$ organisasie en tussen die universiteit en ander organisasies en instellings van die samelewing - vanaf die private sektor, die kerk, kulturele organisasies tot die staat. Wat hierdie kwessie betref, wag daar vir veral Afrikaanstalige universiteite ingrypende 'transformasies'. Nie-universitêre Afrikaanse instellings sal moet aanvaar dat Afrikaanstalige universiteite baie meer onafhanklik en vrygemaak van die gevestigde belange en verwagtings van Afrikaanse instellings moet funksioneer. En, soos reeds gesê, Afrikaanse universiteite sal nie meer oor 'n politieke veiligheidsnet beskik nie.

\section{* Die Afrikaanse karakter van universiteite}

Die tweede sensitiewe kwessie hou verband met die Afrikaanse karakter van Afrikaanstalige universiteite. Daar bestaan goeie aanduidings dat die idee of be- 
Implikasies van die prosesse van transformasie vir die unversifeitsw'ese in Swid-Afrika

ginsel van ' $n$ Afrikaanstalige universiteit nie in die gedrang is nie. ' $n$ Idee of beginsel is natuurlik net een kant van die munt. Of die ontvouende praktiese omstandighede byvoorbeeld begunstigend gaan inwerk op die handhawing en uitbouing van alle bestaande Afrikaanstalige universiteite, is die ander kant van die munt.

Tans is rofweg 50000 universiteitsgeleenthede aan Afrikaans as taalmedium gekoppel. Of dit so sal kan bly, sal nie deur 'beginsels' bepaal word nie, maar deur harde praktiese werklikhede, insluitende finansiële en oorlewingswerklikhede.

Wat hierbo genoem is as agendapunte in 'n herevaluering van die universiteit se rol na aanleiding van die proses van sosio-politieke oorgang, maak hierdie herevaluering geensins maklik nie. Daar kan immers geen twyfel wees nie dat die ontvouende sosio-politieke omgewing vir universiteite in die algemeen en vir Afrikaanstalige universiteite in die besonder beleidmakers voor uitdagings plaas waaroor daar 4-5 jaar gelede nie eens privaat gefluister is nie

Hoe Afrikaanstalige universiteite hierdie uitdagings gaan hanteer, hang onder andere ten nouste saam met wat hulle 'institusionele selfbeeld' genoem kan word, oftewel die wyse waarop hulle hulself as universiteite binne die ontvouende sosio-politieke konteks verstaan. Daarbenewens hang dit ook af van die wyse waarop die nuwe inkomende politieke magselite Afrikaanstalige universiteite beskou. Institusionele vernuwing is immers meer die uitkoms van magstryde rondom skaars hulpbronne, waardestelsels en politieke aspirasies as wat dit die resultaat is van weloorwoë opvoedkundige en onderwysteorieë. Afrikaanstalige universiteite sal nie meer eksklusief kan bepaal wie hulle is en hoe hulle wil wees nie.

Hierdie reeds moeilike en delikate herevaluering vanweë die nuwe sosio-politieke omgewing word meer ingewikkeld gemaak deur die tendense opgesluit in die ander makro-proses waarna verwys is, naamlik die proses van modemiserende ontwikkeling.

Dit is nie moontlik om al die implikasies van die proses van moderniserende ontwikkeling vir die universiteit uit te spel nie. Rossouw (1987) gee daaroor 'n baie insiggewende perspektief. Die meer onmiddellike uitdagings waarvoor die universiteit in Suid-Afrika staan, hou in ieder geval verband met die proses van oorgang. Daar is wel enkele implikasies waarna verwys moet word omdat dit in verband staan met die proses van oorgang. Die een implikasie hang saam met die tendens van operasionalisering, die ander met die tendens van relativering.

\section{* Die operasionaliseringstendens}

Die operasionaliseringstendens sal in Suid-Afrika toenemend versterk word vanweë die heersende konsepsie van die ontwikkelingsbehoeftes van die land, die 
tekort aan finansiële hulpbronne en die groot aksent wat werkskepping ontvang. Nuttigheidsoorwegings begin reeds ' $n$ bepalende faktor vir prioriteite word. Daarom verkeer die geestes- en sosiale wetenskappe ook onder druk, 'in probleem wat nie tipies Suid-Afrikaans is nie, maar wêreldwyd op die agenda staan en onder andere ook verband hou met 'n kwessie wat baie goed weergegee word in die titel van Bouillon en Radnitzsky (1991) se boek Universities in the Service of Truth and Utility.

Hierdie druk op die geestes- en sosiale wetenskappe sal toeneem - enersyds vanweë tegnokrate se reduksie van die ontwikkelingsbehoeftes van die land tot dit wat kwantifiseerbaar en tegnologies hanteerbaar is. Andersyds sal die druk op die geestes- en sosiale wetenskappe ook toeneem vanweë die elitistiese en akademies sektariese wyse waarop die geestes- en sosiale wetenskappe beoefen is. Trouens, geestes- en sosiale wetenskaplikes in Suid-Afrika - en veral dié aan Afrikaanstalige universiteite - sal net hulleself te blameer hê as hulle ervaar dat hulle as akademies én polities 'irrelevant' beskou word. Talle het immers die sosiale konteks van hulle vakbeoefening só eng gedefinieer dat die ontvouende sosiale werklikhede van Suid-Afrika reeds besig is om by hulle verby te gaan. Wie het byvoorbeeld ooit aan Afrikaanstalige universiteite kon droom dat die kliniessielkundige hantering van 'n baie groot persentasie van die nuwe geslag wat die kultuur van geweld en vorme van onderdrukking eksistensieel ervaar het, ook opleidings- en navorsingseise aan Afrikaanse sosiale en geesteswetenskaplikes stel?

Voeg ' $n$ mens by dit alles die feit dat daar reeds ' $n$ tendens werksaam is waardeur die universiteitsgeleide geestes- en sosiale wetenskappe verdring word deur wat Claude Karnoouh (1989:112) die "media-made social science" noem, dan is dit duidelik dat geestes- en sosiale wetenskaplikes binne die verband van moderniserende ontwikkeling nie kan bekostig om hulle belang as vanselfsprekend te aanvaar nie.

Universiteite sal ongetwyfeld ook toenemend voor die vraag te staan kom of hulle primêr opleidingsinstansies is - en slegs sekondêr met kulturele vorming en opvoeding te make het. Trouens, binne 'n ontwikkelende samelewing soos SuidAfrika is die kanse relatief goed dat die relevansie en nut van universiteite bepaal sal word deur die vraag of die universiteit 'produkte' lewer wat vir die gemeenskap 'bruikbaar' is. Hoe universiteite kollektief en individueel op hierdie druk sal reageer - ás hulle wel reageer - sal medebepalend wees vir die vraag wat die verhouding tussen die sogenaamde 'identiteit' en 'relevansie' van die universiteit sal wees.

\section{* Tegnologie-beleid vir Suid-Afrika}

Bogenoemde hou ten nouste verband met 'n saak wat reeds in Suid-Afrika op die agenda staan en wat byvoorbeeld ook deur ' $n$ organisasie soos die ANC ge- 
debatteer is, naamlik ' $n$ tegnologie-beleid vir Suid-Afrika. Dit spreek vanself dat die beleid wat geformuleer en aanvaar gaan word, ' $n$ wesenlike invloed op universiteite sal hê

Dit is opvallend dat die soort posisies wat in die verband ingeneem word, gedra word deur 'n byna messiaanse beskouing oor die wonderwerkende vermoë van die moderne tegnologie. Dit geld vir diegene wat die tegnologie wil aanwend om Suid-Afrika se mededingendheid in die wêreld te verhoog, sowel as vir diegene wat meen dat die ontwikkelingsbehoeftes en onderwyskrisis van die land ten beste - indien nie alleen nie - deur die aanwending van die tegnologie opgelos kan word. Wat hierdie kwessies betref, staan ons reeds voor die uitdaging om die belang van mededingendheid met die belang van ontwikkeling te balanseer - én in hierdie proses in gedagte te hou dat die ontsluiting van mensepotensiaal baie meer as bloot tegnologiese innovasie vra.

\section{- Die debat oor waardes}

'n Tweede punt wat aangeroer moet word, en wat met die tendens van relativering verband hou, is die rol wat die universiteit kan en moet speel in die debat oor waardes wat tans in Suid-Afrika gangbaar is.

Die wins van die huidige oorgangsproses en van die relativerende krag van moderniserende ontwikkeling is dat geykte waardes nie meer as vanselfsprekende gegewenhede met ewigdurende status aanvaar kan word nie. Ons is gedwing om daaroor in 'n debat te tree - en na 'n konsensus te soek wat die grense van eksklusiewe groepies van die verlede oorskry. Horisontalisering van gesagsverhoudinge maak dit ook moeilik, indien nie onmoontlik nie, vir eksklusiewe groepies om eensydig te bepaal wat as waardekonsensus sal geld.

Hierdie debat sal binne én tussen universiteite moet opklink - dit is ' $n$ debat wat immers reeds gevoer word - in byvoorbeeld die sakegemeenskap asook tussen politieke partye. Die vraag is alleen of en hoe die universiteit daaraan gaan deelneem

Dis wel ' $n$ tragedie dat talle sakelui wat ernstig oor die kwessie van waardes, etiek en sosiale verantwoordelikheid voel, van mening is dat hulle nie daaroor by die universiteit kers kan kom opsteek nie. Hulle oordeel is meestal dat daar aan die universiteit ' $n$ waarde- en morele taal gepraat word wat geen eggo in die werkplek vind nie en wat daarop dui dat universiteitsdosente - die uitsonderings uitgesluit - nie hulle insigte in beleid of in meer konkrete terme kan vertaal nie

Dié aanklag mag wel oordrewe wees en ook op ' $n$ misplaaste konsepsie van die funksie van 'n universiteit berus. Daarteenoor moet wel gesê word dat prosesse van moderniserende ontwikkeling en die soort waardedebatte wat daarmee gepaard gaan, vereis dat universiteite hulleself nie van die problematiek van die tyd 
sal isoleer deur ' $n$ vorm van intellektuele kastevorming nie - waar daar net na mekaar se 'taal' geluister word omdat dit al is wat verstaan word.

Daar is heelwat ander kwessies wat ook aangeroer kan word wanneer ons fokus op die medium- tot langtermyngevolge van prosesse van moderniserende ontwikkeling, veral in 'n land soos Suid-Afrika waar die oorgrote meerderheid van die burgery nog in 'n agrariese kultuurpatroon leef, dink en voel. Watter soort rol universiteite in hierdie transformasieproses kan of behoort te speel, nie net in Suid-Afrikaanse verband nie, maar ook in Afrikaverband, is vrae wat om antwoorde soek.

'Trouens, universiteite in die algemeen en Afrikaanstalige universiteite in die besonder sal van die vrae wat op die transformasie-agenda staan, vir hulleself individueel moet kontekstualiseer én konkretiseer. Hoe die Universiteit van Stellenbosch sy partikuliere rol binne die demografiese en sosio-ekonomiese opset van Wes-Kaapland sal interpreteer, sal nie noodwendig ooreenstem met die wyse waarop die Potchefstroomse Universiteit vir Christelike Hoër Onderwys dit sal doen nie. Universalisme en pluralisme (insluitende partikularisme) sal op 'n kreatiewe wyse deur individuele universiteite gesinkroniseer moet word binne die konteks waarin hulle meen hulle funksioneer.

\section{Slotsom}

Dit moet aanvaar word dat die prosesse van oorgang en van moderniserende ontwikkeling die volgende vir die universiteit binne Suid-Afrikaanse konteks inhou:

* 'n Transformasie van die universiteit self asook van die uitreikingstaak daarvan

* 'n Baie groter, meer dinamiese, innoverende en gekontekstualiseerde verantwoordelikheid vir die universitêre opvoedkundige stelsel in die algemeen en doseer- en navorsingsprioriteite in die besonder.

* ' $n$ Baie meer doeltreffende beleid - en strategie - om bepaalde wanbalanse ten opsigte van studentesamestelling, dosentekorps en administratiewe personeel reg te stel.

In dié verband is 'n woord van Russell Berman (1989:116) ook vir Suid-Afrika gepas:

To diagnose the current malaise by positing some golden age of the past, when professors were brilliant and students were smarter, is not helpful at all, but only leads to an incapacitating nostalgia. Nor would such an account be plausible, since the university was always problematic in the sense that its intellectual mission was always contaminated by heterogenous 
Implikasies van die prosesse van transformasie vir die umiversiteitswese in Suid-Afrika

elements: dependence on the state, social elitism, cultural conservatism, etc The point is rather to identify the particular contradictions in the contemporary university, and between the university and its context, and to formulate a strategy that makes the best out of the real situation without relinquishing a vision that may well be very far from current reality.

\section{Bibliografie}

ASHBY, ERIC 1974. Adapting Universities to a Technological Society. London : JosseyBass Publishers

BERMAN, RUSSELL A. 1989. Perestroika for the University. Telos, 81:115-121.

BERSTECHER, D. e.a. 1974. A University of the Future. Den Haag : Martinus Nijhoff.

BLOOM, ALAN 1987. The Closing of the American Mind: How Higher Education has Failed Democracy and Impoverished the Souls of Today's Students. New York: Simon and Schuster.

BOUILLON, H. \& RADNITZSKY, G. eds. 1991. Universities in the Service of Truth and Utility. New York : Peter Lang.

DAHL, R.A. 1971. Polyarchy: Participation and Opposition. New Haven : Yale University Press.

EZRAHI, YARON 1990. The Descent of Icarus. Science and the Transformation of Contemporary Democracy. Cambridge : Harvard University Press.

GOULDNER, ALVIN W. 1979. The Future of Intellectuals and the Rise of the New Class New York : Seabury Press.

HEINRICH, KLAUS 1989. The Spiritual Impoverishment of the German University. Telos, 81:91-97, Fall.

HUNTINGTON, S.P. 1991. The Third Wave. Democratization in the Late Twentieth Century. Norman : University of Oklahoma Press.

KARNOOUH, CLAUDE 1989. Notes on the Crisis of the University. Telos, 81:111-113, Fall.

MARIEN, MICHAEL 1992. Education and Learning in the 21 st Century. Vital Speeches of the Day: 340-344, March 15.

MULLER-SCHWEFE, H-R. 1971. Technik und Glaube. Eine permanente Herausforderung Göttingen : Vandenhoeck \& Ruprecht.

O'DONNELL, G \& SCHMITTER, P.C. 1986. Transitions from Authoritarian Rule: Tentative Conclusions about Uncertain Democracies. Baltimore : John Hopkins University Press

PETERS, TOM. 1992. Liberation Management. London: Macmillan.

ROSSOUW, H.W. 1987. Uitdagings aan die Universitêre onderwys. A.J. Brink geleentheidslesing. Stellenbosch : Universiteit van Stellenbosch.

ROSSOUW, H.W. 1989. Die Universiteit by die kruispad. D.F. Malherbe-Gedenklesing, 8 Acta Varia. Bloemfontein : Universiteit van die Oranje Vrystaat.

ROTHMAN, STANLEY. 1992. Universities in Transition. Dialogue, 98, (4): 41-46

RUSTOW, D.A. 1970. Transitions to Democracy. Toward a Dynamic Model. Comparative Politics: 2, April

VAN DER MERWE, W. 1989. Die hedendaagse Westerse kultuur. Koers, 54 (3):344-358, September

WINNER, LANGDON. 1992. Citizen Virtues in a Technological Order. Inquiry, 35(3/4) 341-362, September.

ZIMAN, JOHN. 1977. The Force of Knowledge. The Scientific Dimension of Society Cambri.lge : University Press. 